\title{
Editorial
}

\section{EUROPEAN SOVEREIGNTY}

On 10 January 2017 at Berlin's Humboldt University, a young man gave a speech in the famous Humboldt series. Emmanuel Macron, then still only a candidate for the French presidency, seized the opportunity to lay out his plans for building 'A Europe of Sovereignty'. In an op-ed article in the Financial Times two weeks later, he was even more outspoken: 'Sovereignty has become the great cause of our time'.

When Macron subsequently won the presidential elections on 7 May 2017, his European sovereignty obtained, along with his other plans, fresh electoral sanction and political drive. Since then he has reiterated the plans on several occasions. Almost invariably, he involves Europeans in this sovereignty. The FT piece concluded 'It is time for Europeans to become sovereign'.

What is the importance of these ideas, and what is their relevance for our journal? Our colleague Franz Mayer, of Bielefeld, wrote on the Verfassungsblog that Macron, by presenting his plans for Europe in such great detail, had put his political life in the balance; he will inevitably be judged by the results, which could well fall short of what has been put at stake. But precisely the height of the drop (Fallhöhe) gave his Sorbonne speech of 26 September 2017 (immediately after the German elections) a significance unequalled by any of the recent proposals from the Commission or any of the other EU presidents. Mayer also briefly discusses Macron's Souveränität Europas, on the one hand by explaining Macron's emphasis on the concept by placing it in the context of the French political arena in which souverainistes and advocates of 'more' Europe stand opposite each other, and on the other by noting that Macron 'reduces sovereignty to a core which is still

\footnotetext{
${ }^{1}$ Emmanuel Macron on Sovereignty: Berlin, 10 January 2017 (Humboldt), < www.rewi.hu-berlin. de/de/lf/oe/whi/FCE/2017/rede-macron > ; Financial Times 24 January 2017 'Europe holds its destiny in its own hands', <www.ft.com/content/3d0cc856-e187-11e6-9645-c9357a75844a >; Athens, 7 September 2017, <en-marche.fr/articles/discours/discours-president-athenes > ; United Nations, 19 September 2017, < en-marche.fr/articles/discours/discours-president-nations-unies > ; La Sorbonne, 26 September 2017 (English version), www.elysee.fr/assets/Initiative-for-Europe-a-sovereign-uniteddemocratic-Europe-Emmanuel-Macron.pdf>, all visited 24 January 2018; Révolution, Paris 2017 (1st 2016), with the inaugural address of 7 May 2017.
} 
plausible today: self-determination'. ${ }^{2}$ Former judge of the Bundesverfassungsgericht Dieter Grimm was less forthcoming. In the Frankfurter of 15 November, he wrote, essentially, that if Macron intended for the EU to become a state, his ideas would be in contradiction with the German constitution. If he meant something else, his notion of sovereignty would be nothing more than metaphor. ${ }^{3}$

The editorial board of EuConst, including the present authors, is also of two minds. Most of us are not sure whether Macron's ideas about European sovereignty offer anything new for constitutional law; some of us find them incoherent and confused. Others, however, find them promising. What if, in light of the doubts and just for the intellectual fun of it, we were to allow for the possibility that Macron's paradoxical notion of European sovereignty could indeed be underpinned by constitutional analysis? ${ }^{4}$

So far, the notion of sovereignty has not sat easily with European integration in constitutional and legal doctrine. There are several doctrinal versions of the relationship between the EU and the sovereignty of the member states. First, there is the doctrine holding that sovereignty gradually loses relevance in the context of European integration. Another reading of the situation is that the EU is gradually taking over sovereignty from the member states in the form of competences and with the legal precedence of EU law. Then there is constitutional pluralism, in which sovereignty remains crucial, but is a mere 'claim to authority' of a polity in

${ }^{2}$ F.C. Mayer, 'Der europäische Sisyphos: ein Kommentar zur Europa-Rede Emmanuel Macrons in der Sorbonne', VerfBlog, 27 September 2017, < verfassungsblog.de/der-europaeische-sisyphosein-kommentar-zur-europa-rede-emmanuel-macrons-in-der-sorbonne/ > , visited 24 January 2018.

${ }^{3}$ The article in the FAZ of 15 November 2017 cannot be retrieved, but references to it appears, among others, in a subsequent interview with Grimm on the Humanist website, 21 December 2017, in which Grimm is quoted: 'Macron hat in seiner Sorbonne-Rede nicht näher erläutert, was er sich unter einem souveränen Europa vorstellt. Wenn man ihn beim Wort nimmt, also das gebräuchliche Verständnis von Souveränität zu Grunde legt, dann hieße das: Selbstbestimmung für die Europäische Union und damit zugleich das Ende der Selbstbestimmung der Mitgliedstaaten. Mit den Grenzen der Integration, die das Bundesverfassungsgericht im Lissabon-Urteil aus dem Grundgesetz abgeleitet hat, wäre das unvereinbar. Solange das Grundgesetz in Kraft ist, könnte sich Deutschland an einer Souveränitätsübertragung und der damit einhergehenden Verstaatlichung der EU nicht beteiligen, und folglich wäre sie ausgeschlossen. Sollte „souverän“ dagegen nur bedeuten, dass weitere Politikfelder vergemeinschaftet würden, zum Beispiel die Verteidigung, oder dass Europa selbstbewusster gegenüber den USA auftritt, wäre das nur eine bildhafte, keine begriffsscharfe Redeweise über Souveränität': <www.humanistische-union.de/nc/aktuelles/ aktuelles_detail/back/aktuelles/article/solange-das-grundgesetz-in-kraft-ist-koennte-sich-deutschland-aneiner-verstaatlichung-der-eu-nicht->, visited 24 January 2018. See also a comment in Merkur, <www. merkur-zeitschrift.de/2017/12/07/das-europa-der-alten > , visited 24 January 2018.

${ }^{4}$ This was done previously by the first of the present authors in two Dutch newspaper articles and in an as yet unpublished keynote address to the Dutch Conference of Constitutionalists of 15 December 2017: Volkskrant, 29 September 2017, <www.volkskrant.nl/opinie/frankrijks-soevereiniteit-moet-europeesworden $\sim$ a4519098/> and Volkskrant, 22 December 2017, <www.volkskrant.nl/opinie/nationale-eneuropese-soevereiniteit-vullen-elkaar-juist-aan a4547809/ > , both visited 24 January 2018. 
general, with the state losing its special status. In each of these readings, as in prevailing general views, there is at least a tense or even contradictory relationship between the EU and the sovereignty of its member states.

In Macron's notion there is no such necessary contradiction; quite the contrary: there is synergy. His views are not alien to ideas of multilevel or composite constitutions and to the old notion of 'shared sovereignty'. But while the latter primarily serve as doctrinal or justificatory tools in the realm of constitutional law, Macron's European sovereignty is militant, political, defiant: 'we must reconquer our sovereignty'. First of all, he wants to keep the idea of sovereignty from being hijacked by populists. One could not agree more. In his speech at the UN General Assembly on 19 September 2017, Macron applied his notion of sovereignty to rebut the US president Donald Trump. While Trump in New York glorified sovereignty as the independence of states from international organisation, Macron, a few hours later from the same rostrum, defended sovereignty as a key attribute of multilateralism.

The objection can be raised that sovereignty, in a political context and in political speech, needs to be seen as different from sovereignty in a legal, judicial or doctrinal context. Surely there are differences in the way the term is used, certainly when used in a legal as opposed to a political discourse. But to allow the claim of coherence to go unheeded in a notion is not a serious option for scholarship, which uses coherence as a critical and empowering quality. This certainly counts for sovereignty, to which the claim to and need for coherence in political action are crucial.

So, what does Macron intend when he refers to 'European sovereignty' or 'Europe of sovereignty'? Does he mean the sovereignty of the EU? No, he does not; quite the contrary, he wants the member states to realise their sovereign authority in the context of the EU, with Germany's Federal Republic as the model of a state which builds its own democratic sovereignty on its EU membership. ${ }^{5}$ Macron wants the other states, beginning with France, to follow that model, and for the EU as a whole to profit.

Quite interestingly, his idea is not so far from that of the German Bundesverfassungsgericht. In most respects, the French president and the German

\footnotetext{
${ }^{5}$ In his Humboldt speech Macron referred to Joschka Fisher's speech of 2000 and to the classic paper by Lamers and Schaüble of 1994, quoting from this: 'Sicherheit nach außen zugewährleisten, sich selbst verteidigen zu können, ist aber Voraussetzung und innerster Kern jeglicher Souveränität von Staaten. Dies gilt demnach für die EU als Gemeinschaft von Staaten in dem Sinne, dass sie überhaupt nur noch so, durch die Gemeinschaft Souveränität erhalten können' (emphasis added by us). Most interesting and topical is how Macron's French election has found expression in the German draft agreement between Christian Democrats and Socialists of 12 January 2018, which proceeds from the need for a Neuer Aufbruch für Europa, an unmistakable gesture of support for Macron's Refondation européenne. Macron's proposal for a new Elysée Treaty is also seconded. See website CDU, visited 18 January 2018.
} 
court are even in full agreement on sovereignty. Both see sovereign authority as crucial for their respective states. Both are outspoken against belittling the notion and finding sovereignty outdated. Both find sovereign authority to be at the heart of the national constitution. And both define the concept in terms of selfdetermination. ${ }^{6}$

Between the two there are, however, some minor but enlightening differences. The Court's sovereignty is mostly defensive, while the President's is assertive. The Court's is oriented towards the past and at establishing closure; Macron's notion embraces the future and welcomes new overtures. While the Court's sovereignty is grounded in legality and covers the German public sphere, President Macron's notion is pointedly aimed at political action and at the Europeans, and not at legal interpretation.

Most importantly, Macron views sovereignty as a form of authority which is not static, but which evolves. That, in our view, is what he indicates with the use of the term European sovereignty. As a conceptual novelty, it may serve to account for the development of relationships between states' authorities, and perhaps also within states. The term national sovereignty may allow us a peek at what he really means. National sovereignty forms a stage in the development of sovereign authority. National sovereignty originated with the nation state, hundreds of years after sovereignty itself originated as ultimate, princely authority. Princely sovereignty has been overlaid, first by parliamentary, then by popular sovereignty, and with each progression the sovereignty of the state has not only been consolidated, but even strengthened. Likewise, national sovereignty may be consolidated and strengthened by the European sovereignty of the member states, individually and collectively. That is the way evolution works. We humans are still animals, but our animal intelligence has been overlaid, first with human forms and a structure of intelligence, and from then on, with increasingly sophisticated social, cultural and political forms and structures of intelligence. Sovereignty, incidentally, is part of the latter.

How to see what this can bring? In the traditional notion of national sovereignty, as followed by the German court, further European integration can only lead to a loss of sovereignty. Following Macron, however, we may look for instances of EU action bringing an increase of state authority. In this respect, the differences between Macron and the German constitutional court are enlightening.

Take the recent (final) OMT ruling by the Bundesverfassungsgericht. As is its tradition, the Court went to great lengths to show how the ECB's decision of 2012

${ }^{6}$ BVerfG 30 June 2009, 2 BvE 2/08, para. 224: 'Souveräne Staatlichkeit steht danach für einen befriedeten Raum und die darin gewährleistete Ordnung auf der Grundlage individueller Freiheit und kollektiver Selbstbestimmung'. 
had barely managed to steer clear of fatally affecting German sovereignty and identity. ${ }^{7}$ Now, did the Court ever even consider the possibility that the Bank's OMT decision might have come in defence or in support of German sovereignty? Since the Court did no such thing, the question is a rhetorical one; that would have gone beyond its legal remit in terms of competences. Had it done so, however, it would have allowed itself (and doctrine) to discover and acknowledge that EU institutions, in which German authorities participate, did defend German sovereignty and, by successfully doing so, asserted and even ensured it. Indeed, as Angela Merkel has hypothesised on several occasions: had the euro gone down, the EU would have gone down with it, and, one might add, Germany's sovereignty would have emerged greatly weakened.

What if the Court had indeed allowed itself to acknowledge this assertion of German sovereignty through the agency of European institutions, and, notably, the Central Bank (backed by the European Council)? Instead of presenting us with a picture of the German republic on the verge of losing its sovereign statehood, imagery increasingly at odds with the most obvious reality, it would have shown us German sovereignty emerging triumphantly from the crisis, together with the sovereignties of the other euro-states. And it would have allowed itself and ourselves to see Germany for what it is: a state successfully defending its (shared) sovereign currency and still maintaining a leading position in global terms, with uncontested internal sovereign control.

The notion of European sovereignty allows us, consequently, to see not just the risk of a loss of national sovereign authority to the EU, but also the potential benefits to be won at the Union level, for each state individually, and for all together. In the same way that previous innovations to the notion of sovereignty the latest of which was national sovereignty - had in fact signified a sophistication and a strengthening of the sovereignty of the state concerned, European sovereignty may signify a new stage of sophistication of state sovereignty for EU member states.

But what about us Europeans, so emphatically drawn into the picture by Macron? While we are not exactly sure what Macron wants when he says he wants to 'make Europeans sovereign', he at the very least acknowledges that the Union's constitutional organs, and notably the European Parliament, fulfil a real representative function - something the Court refuses to do.

The Court's refusal dates back to the Maastricht Urteil and was reiterated in the Lissabon Urteil. In the latter decision, due to the Treaty Change of Lisbon, refusal amounted to a conflict with the law. While Articles 10(2) and 14(2) of the Lisbon version of the TEU assign the representation of EU citizens, or Europeans, to the European Parliament, the Court maintains that the European Parliament only

\footnotetext{
${ }^{7}$ BVerfG 21 June 2016, 2 BvR 2728/13.
} 
represents member states' peoples. ${ }^{8}$ This is an incongruous position. Is not a treaty such as the Treaty of Lisbon a political and legal expression of state sovereignty par excellence?

Macron's involvement of Europeans in his notion of European sovereignty is not meant to do away with the national sovereignty of the member states. In his Athens speech, he said: 'Je crois dans la souveraineté, les souverainetés nationales qui sont les nôtres, mais je crois dans cette souveraineté européenne'. Nor does he, consequently, intend to replace popular sovereignty in the member states that adhere to this formula with popular sovereignty in the Union. The internal structure of authority in member states, including the formal allocation of final authority to a partly nominal entity, remains up to every state. As little as European sovereignty means the sovereignty of the $E U$, it means the popular sovereignty of the Europeans. The only thing it may accomplish is to acknowledge or allow an overture, an extra opening, through which the ultimate authority of the member states can breathe and inhale current European reality. Sovereignty of us Europeans may account for the modest reality of ourselves, having lived through the Eurocrisis and the refugee crisis and the political answers given, not only as French, Germans or Italians, but also, perhaps only a little bit to begin with, as Europeans?

Many topics have thus been opened for analysis. How can European sovereignty help us to understand the evolution of the old (and evolving) relationship between external and internal sovereignty in the member states? How can it help us to understand the evolving constitution of the $\mathrm{EU}$ and the evolution of the member states as members of the EU, in terms of executive, representative and judicial authority?

When in dubiis, let us not abstain. Let us claim the topic for our field and turn the doubts into questions.

WTE/JHR

${ }^{8}$ BVerfG 30 June 2009, 2 BvE 2/08, para 284: Das Europäische Parlament bleibt vor diesem Hintergrund in der Sache wegen der mitgliedstaatlichen Kontingentierung der Sitze eine Vertretung der Völker der Mitgliedstaaten. 